\title{
Nutritional management in patients with chronic kidney disease
}

\author{
Sun Moon $\mathrm{Kim}^{1}$ and Ji Yong Jung ${ }^{2,3}$
}

\begin{abstract}
${ }^{1}$ Division of Nephrology, Department of Internal Medicine, Chungbuk National University Hospital, Cheongju; '2Division of Nephrology, Department of Internal Medicine, Gachon University Gil Medical Center, Incheon; ${ }^{3}$ Department of Internal Medicine, Gachon University College of Medicine, Incheon, Korea
\end{abstract}

\section{Received: August 10, 2020}

Accepted: September 9, 2020

\section{Correspondence to \\ Ji Yong Jung, M.D.}

Division of Nephrology,

Department of Internal

Medicine, Gachon University

Gil Medical Center, 21

Namdong-daero 774beon-gil,

Namdong-gu, Incheon 21565 ,

Korea

Tel: +82-32-458-2621

Fax: +82-32-460-3431

E-mail:jyjung@gachon.ac.kr

https://orcid.org/oooo-0003-

1271-8012

This paper was contributed

by The Korean Society of

Nephrology.
The global prevalence of chronic kidney disease (CKD) is increasing with the aging of populations worldwide. As kidney function declines, the accumulation of metabolic waste products and excessive electrolytes can significantly impair the health of patients with CKD. As nutritional management of patients with CKD is thought to control uremic symptoms and provide beneficial effects on the progression of kidney dysfunction, the diet of patients with CKD should be an important consideration in their care. Many guidelines recommend limiting protein intake in these patients, as high-protein diets aggravate kidney dysfunction. Excess sodium may be associated with CKD progression and all-cause mortality and, therefore, limiting salt intake is generally recommended. Low potassium is associated with muscle weakness and hypertension, whereas high potassium is associated with cardiac arrhythmia. Therefore, recent guidelines recommend adjusting dietary potassium intake on an individual basis to maintain serum potassium levels within the normal range. Appropriate dietary calcium intake is recommended to maintain calcium balance in patients with CKD G3, G4. Given the many dietary considerations for patients with CKD, effective nutritional management is challenging. Individualized strategies are needed to ensure the best outcome for patients with CKD.

Keywords: Diet, protein-restricted; Nutrients; Progression of chronic kidney disease; Individualization

\section{INTRODUCTION}

Chronic kidney disease (CKD) occurs due to structural or functional kidney impairment for more than 3 months, and is divided into five stages according to the decline in glomerular filtration rate (GFR) from early CKD to kidney failure (KF). In Korea, the prevalence rates of CKD and KF have been increasing in recent decades with the increase in the older population and the prevalence of diabetes $[1,2]$. Chronic inflammation in pa- tients with CKD can induce protein catabolism through increased insulin resistance, and protein catabolism can significantly impair an individual's nutritional status $[3,4]$. Patients with CKD may experience hyperkalemia, hyperphosphatemia, anorexia, as well as muscle and fat wasting. Protein-energy wasting (PEW) was first described in 2007 by the International Society of Renal Nutrition and Metabolism as a state of nutritional and metabolic derangements characterized by the loss of systemic body protein and energy stores in patients with 
non-dialysis CKD and KF [5]. The prevalence of PEW in patients with early to moderate CKD was reported to be $20 \%$ to $25 \%$, increasing as kidney dysfunction progresses up to $75 \%$ in KF [6]. Malnutrition, decreased physical activity, uremia-induced hypercatabolism, acidosis, and persistent inflammation can all contribute to PEW [7,8], which is associated with increased risks of hospitalization and mortality [9]. Dietary supplementation with adequate protein and energy may reduce PEW. While nutritional therapy for progressive kidney dysfunction remains controversial, previous studies have shown that it can help control uremia, electrolyte and acid-base imbalances, water and salt retention, and mineral and bone disorders (MBD) [3]. Dietary modifications can reduce the accumulation of waste products, which may relieve uremic symptoms and delay the initiation of maintenance dialysis treatment in patients with non-dialysis CKD. Therefore, nutritional management should be considered during all stages of CKD, and all physicians caring for patients with CKD should be aware of the dietary and nutritional requirements of these patients [10]. This review is focused on several aspects of nutritional management in patients with CKD.

\section{PROTEIN}

Protein intake is one of the most widely discussed issues in the nutritional management of CKD. A high-protein diet, defined as intake of $>1.2 \mathrm{~g}$ protein per kilogram of body weight per day (g/kg/day), has been shown to cause significant deterioration in kidney function [11]. High protein intake increases kidney blood flow and elevates intraglomerular pressure, which leads to higher GFR and more efficient excretion of protein-derived nitrogen products. The hyperfiltration induced by high protein intake has been described in several experimental models and clinical studies [12-16]. High-protein diet-induced glomerular hyperfiltration may have deleterious consequences on the kidney and other organs in the long term [11]. Several studies have shown that long-term exposure to a high-protein diet may cause kidney damage and progressive kidney dysfunction $[17,18]$. The Nurses' Health Study evaluated the effects of protein intake on estimated GFR based on serum creatinine $\left(\mathrm{eGFR}_{\mathrm{cr}}\right)$ decline in 1,624 women over 11 years [17]. The results showed that high protein intake was associated with an eGFR ${ }_{c r}$ decline among individuals with decreased kidney function (defined as eGFR of 55 to $80 \mathrm{~mL} / \mathrm{min} / 1.73 \mathrm{~m}^{2}$ ) but not in those with normal kidney function. Recently, Jhee et al. [18] reported that a high-protein diet induced glomerular hyperfiltration and a rapid decline of kidney function in the general population. A high-protein diet increased the risk of kidney hyperfiltration and a rapid decline of kidney function in the general population. While the effects of a high-protein diet in individuals with normal kidney function are controversial, high protein intake should be avoided in patients with CKD or risk of CKD [16,17].

Dietary protein intake has increased to above the recommended level in the general population in Korea over the past 20 years $[19,20]$. According to the Korea National Health and Nutrition Examination Survey (KNHANES) data in 2017 [19], the mean dietary protein intake was $153 \%$ of the recommended intake in men and $128 \%$ in women among the general population in Korea. The major food sources of protein at that time were cereals (12.7\% of total dietary protein intake), pork (11.3\%), and chicken (8.3\%) [19]. A multicenter, observational, prospective study demonstrated that the mean dietary protein intake was $1.1 \mathrm{~g} / \mathrm{kg} /$ day in Korean patients with non-dialysis CKD, and dietary protein intake decreased with decreasing eGFR ${ }_{\mathrm{cr}}$ [21]. Another study showed that the mean protein intake was $0.73 \mathrm{~g} / \mathrm{kg} /$ day in older Koreans, and protein intake was not associated with CKD [22]. In the USA, the average dietary protein intake tends to decrease as CKD progresses [23], and the dietary protein intake in CKD was above the target level for patients with CKD and marginally below the recommended level in the general population [23].

A low-protein diet may preserve kidney function by decreasing kidney capillary hypertension and glomerular hyperfiltration. While experimental evidence suggests that protein restriction can ameliorate glomerular sclerosis, reduce proteinuria, and preserve GFR [24,25], not all clinical studies have shown that low-protein diets provide beneficial effects in patients with CKD. The Modification of Diet in Renal Disease (MDRD) study, the largest controlled trial of dietary protein management in patients with CKD, failed to show a beneficial effect of a low-protein diet. These findings should be interpreted with caution, as the MDRD study had sev- 
eral limitations, including a short follow-up duration and moderately low rate of diet adherence [26]. Nonetheless, most controlled trials and meta-analyses support the beneficial effects of dietary protein restriction [27-31]. A low-protein diet attenuated kidney function decline and delayed the initiation of dialysis in patients with advanced CKD [29,30]. Moreover, dietary protein restriction may improve metabolic dysfunction in CKD. A low-protein diet may improve metabolic acidosis in patients with CKD. Acid is produced by metabolism of proteins. As kidney function declines, there is a tendency toward impairment of acid secretion, which results in chronic metabolic acidosis [11]. Metabolic acidosis impairs protein metabolism, increases muscle catabolism, and aggravates uremic symptoms [32]. A study of supplemented very low-protein diet demonstrated that dietary protein restriction improved metabolic acidosis in patients with advanced CKD [30]. Dietary modification is essential in the management of hyperphosphatemia in patients with CKD, because dietary protein, especially animal protein, is a major source of phosphorus [11]. Dietary protein restriction may be beneficial for control of hyperphosphatemia, which results in better control of CKD-MBD.

A major component of CKD management is inhibition of the renin-angiotensin-aldosterone system (RAAS), which reduces glomerular hyperfiltration and slows the progression of CKD. The combination of RAAS inhibition and dietary protein restriction has been considered to have additive protective effects on kidney disease progression. The additive action of RAAS inhibition and dietary protein restriction can be explained by similar effects in kidney vessels, with a decrease in glomerular pressure and a reduction in kidney fibrosis through inhibition of the transforming growth factor- $\beta$ pathway [24]. In addition, a low-protein diet could directly inhibit kidney RAAS activation independently of kidney hemodynamics [33]. Many studies on the effects of low-protein diets were conducted before widespread use of RAAS inhibition; thus, there is limited evidence regarding the effects of low-protein diet in combination with RAAS inhibition. Two studies showed that a low-protein diet combined with an angiotensin-converting enzyme (ACE) inhibitor resulted in a further reduction in proteinuria $[34,35]$. Compared to the group treated with ACE inhibitor alone, protein restriction further reduced pro- teinuria by $33 \%$. Although, the evidence is insufficient to support the combination of RAAS inhibitors and dietary protein restriction, a low-protein diet is generally recommended in patients with CKD receiving RAAS inhibitors [24].

The major concerns associated with low-protein diets in clinical practice are the risk of PEW and adherence to dietary restrictions $[3,11]$. Several studies evaluating low-protein diets in patients with CKD have shown acceptable safety with no serious complications, and low rates of $\mathrm{PEW}$ and malnutrition. A clinical trial evaluating low-protein diets over 30 months in patients with $\mathrm{CKD}_{4}$, G5 found that most patients showed acceptable adherence to the prescribed dietary protein restriction, and only $0.7 \%$ of participants developed malnutrition [36]. Another study reported that protein restriction in patients with CKD had no effect on body composition or skeletal muscle mass [37]. A diet consisting of 0.6 to $0.8 \mathrm{~g} / \mathrm{kg} /$ day protein with adequate energy intake (30 to $35 \mathrm{kcal} / \mathrm{kg} /$ day) may satisfy dietary needs in patients with CKD, especially if half of the protein is from sources with "high biological value protein" containing the essential amino acids in appropriate ratios and amounts, such as eggs, milk, meat, and fish [3]. While adherence to dietary protein restriction is difficult to predict, good patient-physician communication, education on simplified dietary approaches, and periodic surveillance by a dietitian may improve adherence $[11,38]$.

Although most international guidelines support a low-protein diet in patients with CKD, the protein requirements vary [39,40]. Most guidelines recommend 0.6 to $0.8 \mathrm{~g} / \mathrm{kg} /$ day protein or very-low-protein diet with keto acid analogs for patients with moderate-to-advanced kidney disease $\left(\mathrm{eGFR}_{\mathrm{cr}}<45 \mathrm{~mL} / \mathrm{min} / 1.73 \mathrm{~m}^{2}\right)$ and those with substantial proteinuria (urinary protein excretion > $0.3 \mathrm{~g} /$ day) [3]. Higher protein intake (1.0 to 1.2 $\mathrm{g} / \mathrm{kg} /$ day) is recommended for patients with KF with replacement therapy, as additional protein is needed to prevent PEW [11]. Patients with nephrotic syndrome may benefit from a low-protein diet $(0.8 \mathrm{~g} / \mathrm{kg} /$ day plus $1 \mathrm{~g}$ /day protein for each $1 \mathrm{~g}$ urinary protein excretion over $5 \mathrm{~g}$ /day), while ensuring adequate caloric intake [4]. Furthermore, the target of protein intake should be individualized according to each patient's clinical condition and disease severity. Modest protein restriction to 0.8 to $1.0 \mathrm{~g} / \mathrm{kg} /$ day is recommended for patients with 
nonproteinuric CKD $\mathrm{G} 1, \mathrm{G} 2$, older patients with CKD $\mathrm{G} 3 \mathrm{~b}$, and patients with slowly progressing CKD [11]. Several studies have suggested that the protein source may affect the progression of kidney disease [41,42]. Specifically, red meat intake is associated with increased risk of KF, whereas other protein sources, such as poultry, fish, eggs, or dairy products, showed no association with risk of $\mathrm{KF}$ [41]. In addition, dairy products were associated with lower risk of the incidence and progression of CKD [43,44]. However, there is insufficient evidence to recommend particular protein types for patients with CKD [40]. For adequate nutrition, we suggest that patients with CKD receive at least half of their protein intake from sources with "high biological value."

\section{SODIUM}

High sodium intake has deleterious effects on blood pressure, cardiovascular health, kidney function, and CKD progression [45]. In patients with CKD, dietary sodium restriction is strongly recommended to control fluid retention, lower blood pressure, and reduce cardiovascular risk [46]. A randomized controlled trial showed that sodium restriction resulted in reduction of blood pressure, extracellular fluid volume, and proteinuria in patients with moderate-to-severe CKD [47]. In addition, sodium restriction enhanced the beneficial effects of a low-protein diet and RAAS inhibition by decreasing intraglomerular pressure, suggesting that sodium restriction may decrease proteinuria and slow the progression of CKD [3]. However, there is inconclusive evidence regarding whether dietary sodium restriction can slow the progression of kidney disease or delay the requirement for kidney replacement therapy. A longitudinal study showed that dietary sodium intake was not associated with progression of kidney disease [48], whereas another study found that sodium excretion was associated with CKD progression and all-cause mortality among 3,939 patients with CKD [49]. The highest quartile of urinary sodium excretion ( $\geq 4.5 \mathrm{~g} /$ day) was associated with a $54 \%$ increased risk of CKD progression and a $45 \%$ increased risk of mortality compared with the lowest quartile $(<2.7$ g/day) [49].

Almost all guidelines recommend lowering sodium intake to 2 to $2.3 \mathrm{~g} /$ day in adults [39,40]. Given the risk of hyponatremia and adverse outcomes, dietary sodium intake $<1.5 \mathrm{~g} /$ day is not recommended for patients with advanced CKD as well as patients on dialysis [50]. In Korea, the Dietary Reference Intakes for Koreans recommends $<2 \mathrm{~g} /$ day sodium, corresponding to approximately $5 \mathrm{~g} /$ day salt [20]. In recent years, the dietary sodium intake has decreased among Koreans; however, sodium intake still remains above the recommended level. Among the general population in Korea, the mean sodium intake decreased from 4,586 mg/day in 1,998 to $3,478 \mathrm{mg} /$ day in 2007 [19,20]. According to the KNHANES data for 2017 [19], the mean dietary sodium intake was $212 \%$ of the recommended intake in men and $149 \%$ in women. The survey found that the major food sources of sodium were seasonings and vegetables, such as kimchi. Patients with CKD should be encouraged to avoid processed foods and to prepare their own meals without salty seasoning. Although urinary sodium excretion from 24-hour urine collection is the gold standard for measuring salt intake, 24-hour urine collection is inconvenient. Urinary sodium excretion rate from spot urine or the sodium frequency food questionnaire could be used to evaluate and monitor dietary salt intake. However, urinary sodium excretion was not useful in monitoring the effects of low-sodium diet in patients with CKD [51]. Therefore, it is necessary to evaluate the dietary salt intake and educate patients based on the situation of each patient.

\section{POTASSIUM}

As the main intracellular cation, potassium mediates intracellular electrophysiology and plays an important role in vascular and neuromuscular functions [4]. Serum potassium levels are finely regulated, as low potassium is associated with muscle weakness and hypertension, whereas high potassium can result in ventricular arrhythmia and death [4,52]. Therefore, dietary potassium intake and serum potassium levels are of significant clinical interest. However, few studies have evaluated the effects of dietary modification on serum potassium levels in patients with CKD [3,53].

Several studies have measured urine potassium excretion as a proxy for dietary potassium intake to assess its effect on clinical outcomes [49,54-56]. Nevertheless, lim- 
ited data are available supporting the idea that dietary potassium restriction improves the outcomes of patients with CKD [57-59], and most recommendations are based on opinions. The 2015 American Dietary Guidelines Advisory Committee report recommends a daily potassium intake of 4,700 $\mathrm{mg}(121 \mathrm{mmol})$ for healthy adults [6o]. The National Kidney Foundation Kidney Disease Outcomes Quality Initiative guidelines recommend a potassium intake of 2 to $4 \mathrm{~g} /$ day (51 to $102 \mathrm{mmol} /$ day) for patients with $\mathrm{CKD} \mathrm{G}_{3}, \mathrm{G}_{4}$, but no restrictions (> $4 \mathrm{~g}$ / day or $>102 \mathrm{mmol} /$ day) for those with earlier-stage CKD [61]. Among the general population in Korea [19], the mean dietary potassium intake was reported to be $88 \%$ of the recommended intake in men and $72 \%$ in women, with the major food sources of potassium being cereals, vegetables, and pork. In addition to kidney function and dietary intake, several other factors affect serum potassium levels, including the use of RAAS blockers and beta-blockers, hydration status, acid-base status, glycemic control, adrenal function, catabolic state, and gastrointestinal problems, such as diarrhea, constipation, and bleeding. As there has been limited research on the effects of these factors, an individualized approach for each patient is recommended.

Previous observational studies have shown that a plant-based diet is associated with a slower decline in the $\mathrm{eGFR}_{\mathrm{cr}}$ among patients with CKD [62,63]. Eating more plant-based foods, such as vegetables and grains, in place of animal-based foods, such as red meat, may help prevent and slow the progression of CKD, type 2 diabetes, high blood pressure, and heart disease $[62,63]$. Eating less animal-based foods can lower the acid load and put less stress on the kidneys [62,63]. In addition, plant-based foods that are not highly processed contain phytates. Phytates can bind phosphate, and so we can expect much less phosphate to be absorbed through plant-based foods than highly processed foods. However, a potassium-rich diet, such as a plant-based diet, may be of limited benefit in controlling serum potassium and phosphate levels in patients with kidney dysfunction. Therefore, individualized approaches with regard to dietary potassium intake in patients with CKD should target a normal- to high-potassium diet. In theory, potassium binders may be used to provide a liberalized potassium diet diet that includes fruits and vegetables if there is concern regarding hyperkalemia in patients with CKD. However, there have been no investigations as to whether potassium intake should be modified when taking potassium binders. Most recent guidelines recommend adjusting dietary potassium intake on an individual basis to maintain normal serum potassium levels in patients with CKD [40].

\section{PHOSPHORUS}

Phosphorus is an essential nutrient for maintaining homeostasis and is found in most natural and processed foods. Phosphorus intake is necessary for bone growth and mineralization, as well as for regulation of energy and acid-base homeostasis [4]. Patients with CKD typically maintain normal serum phosphorus levels during the early stages $\left(\right.$ eGFR $\left._{\mathrm{cr}}>45 \mathrm{~mL} / \mathrm{min} / 1.73 \mathrm{~m}^{2}\right)$ by promoting phosphorus excretion with increased fibroblast growth factor 23 (FGF-23) and parathyroid hormone (PTH) levels. However, as CKD progresses, elevated serum phosphate levels or hyperphosphatemia may occur due to resistance to FGF-23 and PTH [64].

Elevated serum phosphorus levels have been associated with increased cardiovascular risk in patients with CKD and in the general population $[65,66]$. A recent study described the mechanism associated with increased cardiovascular risk in hyperphosphatemia, which can cause left ventricular hypertrophy and arterial stiffness via induction of FGF-23 and vascular calcification $[67,68]$. However, the dietary phosphate intake, measured by 24 -hour urine phosphate excretion, had no effect on the development of KF or cardiovascular mortality when the serum phosphorus concentration remained within the normal range [69].

Traditional guidelines suggest maintaining a phosphorus intake of 800 to $1,000 \mathrm{mg} /$ day in patients with CKD G3-5 and KF on dialysis to keep the serum phosphate level within the normal range [70-72]. Among the general population in Korea [19], the mean dietary phosphorus intake was reported to be $170 \%$ of the recommended intake in men and $123 \%$ in women, with the major food sources of phosphorus being cereal, pork, milk, and egg. It is not clear how to limit dietary phosphorus in adult patients with CKD. In addition, the amount and bioavailability of phosphorus are influenced by the type of dietary protein, which is the primary source of 
phosphorus. Guidelines that recommend limiting dietary phosphorus intake often mention concerns about the risk of limiting protein intake in patients with CKD, especially those on maintenance dialysis therapy [73]. Therefore, dietary consultations should include information about protein sources that contain phosphorus and suggestions for cooking phosphate-rich foods that can achieve low phosphorus intake without compromising dietary quality [74]. In addition, patient education on hyperphosphatemia management, including adoption of a low-phosphate diet and on the appropriate use of phosphate binders, may improve phosphate control [75,76]. Nutritional management may incorporate additional plant-based sources of phosphorus, as the gastrointestinal absorption of plant-based phosphorus $20 \%$ to $50 \%)$ is lower than that from animal-based foods (40\% to $60 \%)$ [77]. Moreover, phosphorus-containing food additives in processed and fast foods are of particular concern as they contain inorganic phosphorus, which shows nearly $100 \%$ intestinal absorption [74,77].

Recent guidelines emphasize individualized recommendations following the evaluation of dietary phosphorus intake to maintain serum phosphorus within the normal range in patients with CKD [40]. Restricting the intake of animal-based dietary phosphates and replacement with plant-derived dietary phosphate may be considered to reduce the pill burden of phosphate binders in patients with advanced CKD.

\section{CALCIUM AND VITAMIN D}

Calcium is an electrolyte and multivalent cation that is essential for many bodily functions. It is necessary for the functioning of muscles as well as the circulatory and digestive system, and is essential for bone formation and blood cell synthesis [4]. Calcium balance is strictly regulated by calcium absorption in the intestine, reabsorption in the kidney, and exchange in the bones. Given the important role of the kidneys in calcium balance, the serum calcium level decreases as CKD progresses [78]. Calcium level reduction can cause secondary hyperparathyroidism, which leads to MBDs, whereas extraosseous calcification resulting from excess calcium can lead to cardiovascular disease and increased mortality [79]. Maintaining a balanced serum calcium level in patients with CKD requires consideration of several factors, including kidney function, mineral-controlling hormones, bone turnover, use of vitamin $\mathrm{D}$ analogs, and calcium intake from supplements. For patients requiring maintenance dialysis, additional factors must be taken into consideration, including the mode of dialysis as well as the calcium concentration in the dialysate. Therefore, ensuring adequate dietary calcium is challenging and depends on unique factors affecting each patient's calcium balance.

In 2017, Kidney Disease: Improving Global Outcomes (KDIGO) updated its CKD-MBD clinical practice guidelines to suggest restricting the dose of calcium-containing phosphate binders regardless of serum calcium level [71]. This recommendation was based on evidence from three open-label randomized controlled trials showing improved survival among dialysis patients treated with the phosphate-binding drug, sevelamer, versus calcium-containing binders [8o-82]. However, other researchers raised concerns regarding small sample size, inconsistent findings, and loss to follow-up resulting in risks of bias in this study. Spoendlin et al. [83] reported an observational study suggesting that there is no cardiovascular or survival benefit of sevelamer compared to calcium acetate among incident dialysis patients 65 years or older. These conflicting results should be examined in future clinical trials and reflected in the guidelines.

The recommended daily intake of dietary calcium is 800 to $1,000 \mathrm{mg} /$ day to maintain appropriate calcium levels in patients with $\mathrm{CKD} \mathrm{G}_{3}, \mathrm{G}_{4}$ who are not receiving active vitamin $\mathrm{D}$ analogs [84]. These recommendations are consistent with the current estimated average requirement ( 800 to $1,000 \mathrm{mg} /$ day) and recommended dietary allowance (1,000 to $1,200 \mathrm{mg} /$ day) for healthy individuals according to the National Academy of Medicine in the USA [85]. Among the general population in Korea [19], the mean dietary calcium intake was reported to be $72 \%$ of the recommended intake in men and $63 \%$ in women, with the major food sources of calcium being milk, vegetables, and anchovies.

In addition to dietary intake, vitamin $\mathrm{D}$ is also affected by the degree of sunlight exposure and seasonal changes, making it difficult to establish dietary standards [4]. The prevalence of vitamin D deficiency (20 to $30 \mathrm{ng} / \mathrm{mL}$ ) and insufficiency $(<20 \mathrm{ng} / \mathrm{mL})$, assessed by the serum concentration of calcidiol (25-hydroxyvitamin D [25(OH) 


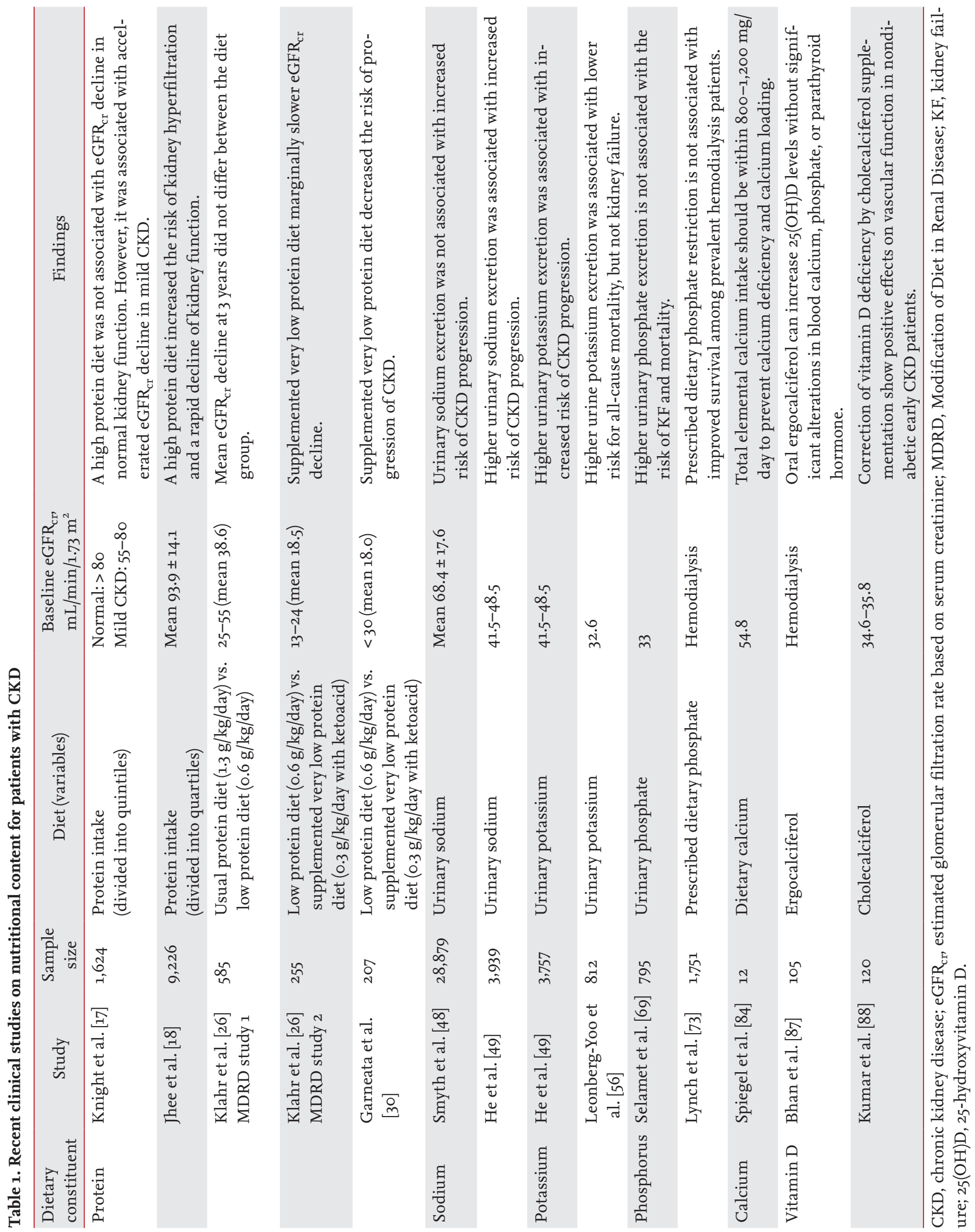


$\mathrm{D}]$ ), is higher in patients with advanced CKD compared with healthy individuals in Korea [86]. Recognizing the increased risk of vitamin D deficiency among patients with $\mathrm{CKD}$, recent guidelines recommend supplementation for vitamin $\mathrm{D}$ deficiency in patients with $\mathrm{CKD}$, but not CKD-MBD or other clinically relevant outcomes $[40,71,72]$. No guidelines specify a safe dose of vitamin D supplementation for preventing side effects in patients with CKD. Therefore, vitamin D supplement regimens should be individualized, and serum calcium, phosphorus and 25(OH)D levels should be measured periodically, especially in patients taking calcium-containing phosphate binders and/or active vitamin $\mathrm{D}$ analogs.

\section{CONCLUSIONS}

This review was based on the best information currently available. When clinicians consider the needs of an individual patient, the resources available, and the limitations inherent to the institution or type of care, variations in practice are inevitable. Based on the articles reviewed (Table 1) $[17,18,26,30,48,49,56,69,73,84,87,88]$, individualized strategies are recommended according to each patient's nutritional status, clinical comorbidities, and disease severity (Table 2). Individualized approaches with periodic counseling may help to attenuate the progression of CKD and decrease mortality. Moreover, detailed nutritional care also improves quality of life. Further research to evaluate the effects of nutritional in-

Table 2. Nutritional recommendations for patients with CKD

\begin{tabular}{|c|c|}
\hline Dietary constituent & Nutritional recommendations \\
\hline Protein & $\begin{array}{l}\text { For patients with } \mathrm{CKD}_{3} \mathrm{~b}, \mathrm{G}_{4}, \mathrm{G}_{5} \text { or patients with proteinuria (urinary protein excretion > } 0.3 \mathrm{~g} / \text { day), } \\
\text { a protein intake of } 0.6-0.8 \mathrm{~g} / \mathrm{kg} / \text { day is recommended. } \\
\text { For patients on dialysis, } 1.0-1.2 \mathrm{~g} / \mathrm{kg} / \text { day is recommended. } \\
\text { For patients with nephrotic syndrome, } 0.8 \mathrm{~g} / \mathrm{kg} / \text { day }+1 \mathrm{~g} / \text { day protein for each } 1 \mathrm{~g} \text { urinary protein ex- } \\
\text { cretion over } 5 \mathrm{~g} / \text { day is recommended. } \\
\text { For patients with nonproteinuric CKD } \mathrm{G} 1, \mathrm{G} 2 \text {, older patients with } \mathrm{CKD} \mathrm{G} 3 \mathrm{~b} \text {, and patients with slowly } \\
\text { progressing CKD, } 0.8-1.0 \mathrm{~g} / \mathrm{kg} / \text { day is recommended. }\end{array}$ \\
\hline Sodium & Less than $2 \mathrm{~g} /$ day sodium (approximately $5 \mathrm{~g}$ salt) is recommended. \\
\hline Potassium & $\begin{array}{l}\text { Individualized regimens to maintain serum potassium levels within the normal range is recom- } \\
\text { mended. } \\
\text { In patients with CKD who exhibit hyperkalemia, consider lowering dietary potassium intake to main- } \\
\text { tain serum potassium levels within the normal range. }\end{array}$ \\
\hline Phosphorus & $\begin{array}{l}\text { In patients with } \mathrm{CKD} \mathrm{G}_{3}-5 \text { and } \mathrm{KF} \text { with replacement therapy, } 0.8-1 \mathrm{~g} / \text { day or individualized regimens } \\
\text { are recommended to maintain serum phosphate within the normal range. } \\
\text { In patients with } \mathrm{CKD} \text { who exhibit hyperphosphatemia, consider lowering dietary phosphorus intake } \\
\text { to maintain serum phosphate levels within the normal range. } \\
\text { Increase vegetable-based phosphors intake and avoid processed foods as much as possible. }\end{array}$ \\
\hline Calcium & $\begin{array}{l}\text { In patients with } \mathrm{CKD} \mathrm{G}_{3}, \mathrm{G}_{4} \text { not taking active vitamin } \mathrm{D} \text { analogs, } 800-1,000 \mathrm{mg} / \mathrm{day} \text { of elemental cal- } \\
\text { cium may be prescribed to maintain normal calcium levels. } \\
\text { In patients with KF with replacement therapy, adjust calcium intake (i.e., dietary calcium, calcium } \\
\text { supplements or calcium-based binders) depending on concurrent use of vitamin D analogs and calci- } \\
\text { mimetics in order to avoid hypercalcemia. }\end{array}$ \\
\hline Vitamin D & $\begin{array}{l}\text { In patients with CKD who exhibit } 25(\mathrm{OH}) \mathrm{D} \text { deficiency, vitamin } \mathrm{D} \text { supplementation in the form of } \\
\text { cholecalciferol or ergocalciferol may be considered only for deficiency/insufficiency, but not for CKD- } \\
\text { MBD or other clinically relevant outcomes. } \\
\text { Vitamin D supplementation regimens should be determined based on individualized strategies, and } \\
\text { serum calcium, phosphorus and } 25(\mathrm{OH}) \mathrm{D} \text { levels should be measured periodically, especially in pa- } \\
\text { tients taking calcium-containing phosphate binders and/or active vitamin D analogs. }\end{array}$ \\
\hline
\end{tabular}

Recommended dietary intake based on current guidelines and recommendations [3,4,39,40,71].

CKD, chronic kidney disease; KF, kidney failure; $25(\mathrm{OH}) \mathrm{D}$, 25-hydroxyvitamin $\mathrm{D}$; MBD, mineral and bone disorder. 
terventions on clinical outcomes in patients with CKD will yield concrete recommendations.

\section{Conflict of interest}

No potential conflict of interest relevant to this article was reported.

\section{REFERENCES}

1. Jin DC. Analysis of mortality risk from Korean hemodialysis registry data 2017. Kidney Res Clin Pract 2019;38:169-175.

2. Jin DC, Yun SR, Lee SW, et al. Current characteristics of dialysis therapy in Korea: 2016 registry data focusing on diabetic patients. Kidney Res Clin Pract 2018;37:20-29.

3. Kalantar-Zadeh K, Fouque D. Nutritional management of chronic kidney disease. N Engl J Med 2017;377:1765-1776.

4. Yu ASL, Chertow GM, Luyckx V, Marsden PA, Skorecki K, Taal MW. Brenner and Rector's the Kidney. 11th ed. Amsterdam (NL): Elsevier, 2019.

5. Fouque D, Kalantar-Zadeh K, Kopple J, et al. A proposed nomenclature and diagnostic criteria for protein-energy wasting in acute and chronic kidney disease. Kidney Int 2008;73:391-398.

6. Kovesdy CP, Kopple JD, Kalantar-Zadeh K. Management of protein-energy wasting in non-dialysis-dependent chronic kidney disease: reconciling low protein intake with nutritional therapy. Am J Clin Nutr 2013;97:1163-1177.

7. Kim JK, Kim SG, Oh JE, et al. Impact of sarcopenia on long-term mortality and cardiovascular events in patients undergoing hemodialysis. Korean J Intern Med 2019;34:599-607.

8. Sun S, Lee H, Yim HW, Won HS, Ko YH. The impact of sarcopenia on health-related quality of life in elderly people: Korean National Health and Nutrition Examination Survey. Korean J Intern Med 2019;34:877-884.

9. Hanna RM, Ghobry L, Wassef O, Rhee CM, Kalantar-Zadeh K. A practical approach to nutrition, protein-energy wasting, sarcopenia, and cachexia in patients with chronic kidney disease. Blood Purif 2020;49:202-211.

10. Pereira RA, Ramos CI, Teixeira RR, Muniz GA, Claudino G, Cuppari L. Diet in chronic kidney disease: an integrated approach to nutritional therapy. Rev Assoc Med Bras (1992) 2020;66 Suppl 1:s59-s67.

11. Ko GJ, Obi Y, Tortorici AR, Kalantar-Zadeh K. Dietary protein intake and chronic kidney disease. Curr Opin Clin
Nutr Metab Care 2017;20:77-85.

12. Hostetter TH, Meyer TW, Rennke HG, Brenner BM. Chronic effects of dietary protein in the rat with intact and reduced renal mass. Kidney Int 1986;30:509-517.

13. Friedman AN, Ogden LG, Foster GD, et al. Comparative effects of low-carbohydrate high-protein versus low-fat diets on the kidney. Clin J Am Soc Nephrol 2012;7:1103-1111.

14. Tirosh A, Golan R, Harman-Boehm I, et al. Renal function following three distinct weight loss dietary strategies during 2 years of a randomized controlled trial. Diabetes Care 2013;36:2225-2232.

15. Schwingshackl L, Hoffmann G. Comparison of high vs. normal/low protein diets on renal function in subjects without chronic kidney disease: a systematic review and meta-analysis. PLoS One 2014;9:e97656.

16. Cirillo M, Lombardi C, Chiricone D, de Santo NG, Zanchetti A, Bilancio G. Protein intake and kidney function in the middle-age population: contrast between cross-sectional and longitudinal data. Nephrol Dial Transplant 2014;29:1733-1740.

17. Knight EL, Stampfer MJ, Hankinson SE, Spiegelman D, Curhan GC. The impact of protein intake on renal function decline in women with normal renal function or mild renal insufficiency. Ann Intern Med 2003;138:460-467.

18. Jhee JH, Kee YK, Park S, et al. High-protein diet with renal hyperfiltration is associated with rapid decline rate of renal function: a community-based prospective cohort study. Nephrol Dial Transplant 2020;35:98-106.

19. Korea Centers for Disease Control \& Prevention. Korea health statistics 2017: Korea National Health and Nutrition Examination Survey (KNHANES VII-2) [Internet]. Cheongju (KR): KCDC, 2020 [cited 2020 Sep 15]. Available from: http://knhanes.cdc.go.kr/.

20. The Korean Nutrition Society. Dietary Reference Intakes for Koreans 2015. Seoul (KR): The Korean Nutrition Society, 2015 .

21. Lee SW, Kim YS, Kim YH, et al. Dietary protein intake, protein energy wasting, and the progression of chronic kidney disease: analysis from the KNOW-CKD Study. Nutrients 2019;11:121.

22. Ko BJ, Chang Y, Ryu S, et al. Dietary acid load and chronic kidney disease in elderly adults: protein and potassium intake. PLoS One 2017;12:e0185069.

23. Moore LW, Byham-Gray LD, Scott Parrott J, et al. The mean dietary protein intake at different stages of chronic kidney disease is higher than current guidelines. Kidney Int 
2013;83:724-732.

24. Koppe L, Fouque D. The role for protein restriction in addition to renin-angiotensin-aldosterone system inhibitors in the management of CKD. Am J Kidney Dis 2019;73:248-257.

25. Bellizzi V. Low-protein diet or nutritional therapy in chronic kidney disease? Blood Purif 2013;36:41-46.

26. Klahr S, Levey AS, Beck GJ, et al. The effects of dietary protein restriction and blood-pressure control on the progression of chronic renal disease. Modification of Diet in Renal Disease Study Group. N Engl J Med 1994;330:877-884.

27. Fouque D, Laville M. Low protein diets for chronic kidney disease in non diabetic adults. Cochrane Database Syst Rev 2009;3:CDoo1892.

28. Nezu U, Kamiyama H, Kondo Y, Sakuma M, Morimoto T, Ueda S. Effect of low-protein diet on kidney function in diabetic nephropathy: meta-analysis of randomised controlled trials. BMJ Open 2013;3:e002934.

29. Ihle BU, Becker GJ, Whitworth JA, Charlwood RA, Kincaid-Smith PS. The effect of protein restriction on the progression of renal insufficiency. N Engl J Med 1989;321:17731737 .

30. Garneata L, Stancu A, Dragomir D, Stefan G, Mircescu G. Ketoanalogue-supplemented vegetarian very low-protein diet and CKD progression. J Am Soc Nephrol 2016;27:21642176.

31. Satirapoj B, Vongwattana P, Supasyndh O. Very low protein diet plus ketoacid analogs of essential amino acids supplement to retard chronic kidney disease progression. Kidney Res Clin Pract 2018;37:384-392.

32. Goraya N, Wesson DE. Dietary interventions to improve outcomes in chronic kidney disease. Curr Opin Nephrol Hypertens 2015;24:505-510.

33. Zhang JY, Yin Y, Ni L, et al. Low-protein diet supplemented with ketoacids ameliorates proteinuria in 3/4 nephrectomised rats by directly inhibiting the intrarenal renin-angiotensin system. Br J Nutr 2016;116:1491-1501.

34. Ruilope LM, Casal MC, Praga M, et al. Additive antiproteinuric effect of converting enzyme inhibition and a low protein intake. J Am Soc Nephrol 1992;3:1307-1311.

35. Gansevoort RT, de Zeeuw D, de Jong PE. Additive antiproteinuric effect of ACE inhibition and a low-protein diet in human renal disease. Nephrol Dial Transplant 1995;10:497504.

36. Cianciaruso B, Pota A, Bellizzi V, et al. Effect of a low-versus moderate-protein diet on progression of CKD: follow-up of a randomized controlled trial. Am J Kidney Dis
2009;54:1052-1061.

37. Dumler F. Body composition modifications in patients under low protein diets. J Ren Nutr 2011;21:76-81.

38. Ikizler TA, Franch HA, Kalantar-Zadeh K, ter Wee PM, Wanner C. Time to revisit the role of renal dietitian in the dialysis unit. J Ren Nutr 2014;24:58-60.

39. KDIGO Working Group. KDIGO 2012 clinical practice guideline for the evaluation and management of chronic kidney disease. Kidney Int Suppl (2013) 2013;3:1-150.

40. KDOQI Work Group. KDOQI clinical practice guidelines for nutrition in chronic kidney disease: 2019 update [Internet]. New York (NY): National Kidney Foundation, 2019 [cited 2020 Sep 15]. Available from: https://www.kidney.org/ sites/default/files/Nutrition_GL\%2BSubmission_101719_ Public_Review_Copy.pdf.

41. Lew QJ, Jafar TH, Koh HW, et al. Red meat intake and risk of ESRD. J Am Soc Nephrol 2017;28:304-312.

42. Joshi S, Hashmi S, Shah S, Kalantar-Zadeh K. Plant-based diets for prevention and management of chronic kidney disease. Curr Opin Nephrol Hypertens 2020;29:16-21.

43. Gopinath B, Harris DC, Flood VM, Burlutsky G, Mitchell P. Associations between dairy food consumption and chronic kidney disease in older adults. Sci Rep 2016;6:39532.

44. Eslami O, Shidfar F. Dairy products and chronic kidney disease: protective or harmful?: asystematic review of prospective cohort studies. Nutrition 2018;55-56:21-28.

45. Wong MM, Arcand J, Leung AA, Thout SR, Campbell NR, Webster J. The science of salt: a regularly updated systematic review of salt and health outcomes (December 2015-March 2016). J Clin Hypertens (Greenwich) 2017;19:322-332.

46. He FJ, Li J, Macgregor GA. Effect of longer-term modest salt reduction on blood pressure. Cochrane Database Syst Rev 2013;4:CDoo4937.

47. McMahon EJ, Bauer JD, Hawley CM, et al. A randomized trial of dietary sodium restriction in CKD. J Am Soc Nephrol 2013;24:2096-2103.

48. Smyth A, Dunkler D, Gao P, et al. The relationship between estimated sodium and potassium excretion and subsequent renal outcomes. Kidney Int 2014;86:1205-1212.

49. He J, Mills KT, Appel LJ, et al. Urinary sodium and potassium excretion and CKD progression. J Am Soc Nephrol 2016;27:1202-1212.

50. Kovesdy CP, Lott EH, Lu JL, et al. Hyponatremia, hypernatremia, and mortality in patients with chronic kidney disease with and without congestive heart failure. Circulation 
2012;125:677-684.

51. Kim SY, Lee YH, Kim YG, et al. Estimating the urinary sodium excretion in patients with chronic kidney disease is not useful in monitoring the effects of a low-salt diet. Kidney Res Clin Pract 2018;37:373-383.

52. Cupisti A, Brunori G, di Iorio BR, et al. Nutritional treatment of advanced CKD: twenty consensus statements. J Nephrol 2018;31:457-473.

53. Kramer H. Diet and chronic kidney disease. Adv Nutr 2019;10(Suppl_4):S367-S379.

54. Kim HW, Park JT, Yoo TH, et al. Urinary potassium excretion and progression of CKD. Clin J Am Soc Nephrol 2019;14:330-340.

55. Koo H, Hwang S, Kim TH, et al. The ratio of urinary sodium and potassium and chronic kidney disease progression: results from the KoreaN Cohort Study for Outcomes in Patients with Chronic Kidney Disease (KNOW-CKD). Medicine (Baltimore) 2018;97:e12820.

56. Leonberg-Yoo AK, Tighiouart H, Levey AS, Beck GJ, Sarnak MJ. Urine potassium excretion, kidney failure, and mortality in CKD. Am J Kidney Dis 2017;69:341-349.

57. Sharma S, McFann K, Chonchol M, de Boer IH, Kendrick J. Association between dietary sodium and potassium intake with chronic kidney disease in US adults: a cross-sectional study. Am J Nephrol 2013;37:526-533.

58. Mun KH, Yu GI, Choi BY, Kim MK, Shin MH, Shin DH. Association of dietary potassium intake with the development of chronic kidney disease and renal function in patients with mildly decreased kidney function: the Korean multi-rural communities cohort study. Med Sci Monit 2019;25:1061-1070.

59. Morris A, Krishnan N, Kimani PK, Lycett D. Effect of dietary potassium restriction on serum potassium, disease progression, and mortality in chronic kidney disease: a systematic review and meta-analysis. J Ren Nutr 2020;30:276285 .

6o. McGuire S. Scientific report of the 2015 Dietary Guidelines Advisory Committee. Washington, DC: US Departments of Agriculture and Health and Human Services, 2015. Adv Nutr 2016;7:202-204.

61. Kidney Disease Outcomes Quality Initiative (K/DOQI). K/ DOQI clinical practice guidelines on hypertension and antihypertensive agents in chronic kidney disease. Am J Kidney Dis 2004;43(5 Suppl 1):S1-S290.

62. Bach KE, Kelly JT, Palmer SC, Khalesi S, Strippoli GF, Campbell KL. Healthy dietary patterns and incidence of
CKD: a meta-analysis of cohort studies. Clin J Am Soc Nephrol 2019;14:1441-1449.

63. Kim H, Caulfield LE, Garcia-Larsen V, et al. Plant-based diets and incident CKD and kidney function. Clin J Am Soc Nephrol 2019;14:682-691.

64. Moranne O, Froissart M, Rossert J, et al. Timing of onset of CKD-related metabolic complications. J Am Soc Nephrol 2009;20:164-171.

65. Dhingra R, Sullivan LM, Fox CS, et al. Relations of serum phosphorus and calcium levels to the incidence of cardiovascular disease in the community. Arch Intern Med 2007;167:879-885.

66. Palmer SC, Hayen A, Macaskill P, et al. Serum levels of phosphorus, parathyroid hormone, and calcium and risks of death and cardiovascular disease in individuals with chronic kidney disease: a systematic review and meta-analysis. JAMA 2011;305:1119-1127.

67. Faul C, Amaral AP, Oskouei B, et al. FGF23 induces left ventricular hypertrophy. J Clin Invest 2011;121:4393-4408.

68. Lee SM, An WS. Supplementary nutrients for prevention of vascular calcification in patients with chronic kidney disease. Korean J Intern Med 2019;34:459-469.

69. Selamet U, Tighiouart H, Sarnak MJ, et al. Relationship of dietary phosphate intake with risk of end-stage renal disease and mortality in chronic kidney disease stages 3-5: the Modification of Diet in Renal Disease Study. Kidney Int 2016;89:176-184.

70. Fouque D, Vennegoor M, ter Wee P, et al. EBPG guideline on nutrition. Nephrol Dial Transplant 2007;22 Suppl 2:ii45ii87.

71. Kidney Disease: Improving Global Outcomes (KDIGO) CKD-MBD Update Work Group. KDIGO 2017 clinical practice guideline update for the diagnosis, evaluation, prevention, and treatment of Chronic Kidney Disease-Mineral and Bone Disorder (CKD-MBD). Kidney Int Suppl (2011) 2017;7:1-59.

72. National Kidney Foundation. K/DOQI clinical practice guidelines for bone metabolism and disease in chronic kidney disease. Am J Kidney Dis 2003;42(4 Suppl 3):S1-S2O1.

73. Lynch KE, Lynch R, Curhan GC, Brunelli SM. Prescribed dietary phosphate restriction and survival among hemodialysis patients. Clin J Am Soc Nephrol 2011;6:620-629.

74. St-Jules DE, Woolf K, Pompeii ML, Kalantar-Zadeh K, Sevick MA. Reexamining the phosphorus-protein dilemma: does phosphorus restriction compromise protein status? J Ren Nutr 2016;26:136-140. 
75. Karavetian M, Rizk R. Patient education for hyperphosphatemia management: improving outcomes while decreasing costs? Kidney Res Clin Pract 2018;37:4-7.

76. Lim E, Hyun S, Lee JM, et al. Effects of education on low-phosphate diet and phosphate binder intake to control serum phosphate among maintenance hemodialysis patients: a randomized controlled trial. Kidney Res Clin Pract 2018;37:69-76.

77. Kalantar-Zadeh K, Gutekunst L, Mehrotra R, et al. Understanding sources of dietary phosphorus in the treatment of patients with chronic kidney disease. Clin J Am Soc Nephrol 2010;5:519-530.

78. Levin A, Bakris GL, Molitch M, et al. Prevalence of abnormal serum vitamin D, PTH, calcium, and phosphorus in patients with chronic kidney disease: results of the study to evaluate early kidney disease. Kidney Int 2007;71:31-38.

79. Sigrist MK, Taal MW, Bungay P, McIntyre CW. Progressive vascular calcification over 2 years is associated with arterial stiffening and increased mortality in patients with stages 4 and 5 chronic kidney disease. Clin J Am Soc Nephrol 2007;2:1241-1248.

8o. Suki WN, Zabaneh R, Cangiano JL, et al. Effects of sevelamer and calcium-based phosphate binders on mortality in hemodialysis patients. Kidney Int 2007;72:1130-1137.

81. Block GA, Raggi P, Bellasi A, Kooienga L, Spiegel DM. Mortality effect of coronary calcification and phosphate binder choice in incident hemodialysis patients. Kidney
Int 2007;71:438-441.

82. Di Iorio B, Molony D, Bell C, et al. Sevelamer versus calcium carbonate in incident hemodialysis patients: results of an open-label 24-month randomized clinical trial. Am J Kidney Dis 2013;62:771-778.

83. Spoendlin J, Paik JM, Tsacogianis T, Kim SC, Schneeweiss S, Desai RJ. Cardiovascular outcomes of calcium-free vs calcium-based phosphate binders in patients 65 years or older with end-stage renal disease requiring hemodialysis. JAMA Intern Med 2019;179:741-749.

84. Spiegel DM, Brady K. Calcium balance in normal individuals and in patients with chronic kidney disease on lowand high-calcium diets. Kidney Int 2012;81:1116-1122.

85. Ross AC, Taylor CL, Yaktine AL, et al. Dietary Reference Intakes for Calcium and Vitamin D. Washington (DC): National Academies Press, 2011.

86. Chang JH, Ro H, Kim S, Lee HH, Chung W, Jung JY. Study on the relationship between serum 25 -hydroxyvitamin D levels and vascular calcification in hemodialysis patients with consideration of seasonal variation in vitamin $\mathrm{D}$ levels. Atherosclerosis 2012;220:563-568.

87. Bhan I, Dobens D, Tamez H, et al. Nutritional vitamin D supplementation in dialysis: a randomized trial. Clin J Am Soc Nephrol 2015;10:611-619.

88. Kumar V, Yadav AK, Lal A, et al. A randomized trial of vitamin D supplementation on vascular function in CKD. J Am Soc Nephrol 2017;28:3100-3108. 